\title{
Preliminary Study on the Brand Construction of Tropical Agriculture against the Background of We-media-A Case Study of Chinese Academy of Tropical Agricultural Sciences
}

\author{
Xiaojun Yuan, Huan Ouyang*, Lifeng Lin \\ Chinese Academy of Tropical Agricultural Sciences, Haikou,571737, China \\ *Corresponding author
}

\begin{abstract}
With the rapid development of electronic industry, "We-media + brand agriculture" model of development also gradually developed, and the tropical agriculture in our country belongs to the "niche" agriculture, awareness is low, in the since the "We-media + brand agriculture" development in our country, is still at a disadvantage, both faces enormous opportunities for development, at the same time to meet the challenge. Taking the Chinese Academy of Tropical Agricultural Sciences as an example, this paper discusses the problems, opportunities and challenges in the brand construction and development of tropical agriculture under the background of "We-media", and puts forward countermeasures and suggestions for the brand development of tropical agriculture.
\end{abstract}

Keywords: We- media,tropical agriculture,brand building

\section{Introduction}

The SARS epidemic in 2002 promoted the rapid development of China's e-commerce industry. Similarly, the COVID-19 epidemic that broke out at the end of 2019 also promoted the rapid development of "We-media" industry. During the epidemic, people were forced to stay at home. Through the "We-media" software, they watched various videos and live broadcasts that attracted them, such as online shopping, cooking, clothing, etc., which was the main entertainment then. Therefore, "We Media" has become an integral part of our life. The development model of "we-media and brand agriculture" has become increasingly popular recently. However, tropical agriculture is a "minority" agriculture in China, which has received little attention. At the critical moment of the development of "we-media and brand agriculture", tropical agriculture still plays the role of a bystander.

\section{Foundation of Tropical Agriculture Brand Development}

\subsection{Tropical agriculture brand cultivation}

By the end of 2019, Chinese Academy of Tropical Agricultural Sciences had made great achievements as follows: 42 registered trademarks, 2 regional brands (Xinglong Coffee and Wenchang Coconut), 1 AAAA tourist attraction, 2 AAA tourist attractions, 2 approved high-tech enterprises (respectively located in Spice and Beverage Research Institute and Haikou Station), 1 advanced enterprise of national intellectual property (Spice and Beverage Research Institute), and 2 approved high-tech enterprises (Spice and Beverage Research Institute), 1 Inspection and Testing Institution (CMA), 1 Inspection Institution of Agricultural Products Quality Safety (CATL), 9 popular science bases, 1 agricultural product that reaches the standards of pollution-free agricultural products, green food, organic agricultural products and geographical indications of agricultural products (black pepper), 2 green food products (jackfruit, red pitaya fruit) and 4 award-winning products (famous brand). Most of the brands have carried out effective operation, achieving certain economic benefits, social benefits and brand effects. In terms of economic benefits, some enterprises have achieved better economic benefits through brand construction and brand management. For example, the Rubber Research Institute has developed a series of products related to rubber trees branded Xiang Feng such as nutrients of cutting planes, efficient protection agents, special fertilizers, electric rubber tapping knives and "Tianjiao" latex products. Its annual revenues have reached 9.05 million yuan. The effective

ISSN: 0010-8189

C CONVERTER 2021

www.converter-magazine.info 
Volume 2021, No. 5

sorting and screening of product brands, enterprise brands, regional brands, etc. (as shown in Fig. 1) has laid a good foundation for the construction and development of a world-class tropical agricultural science and technology brand as well as has expanded the popularity and reputation of tropical agriculture.

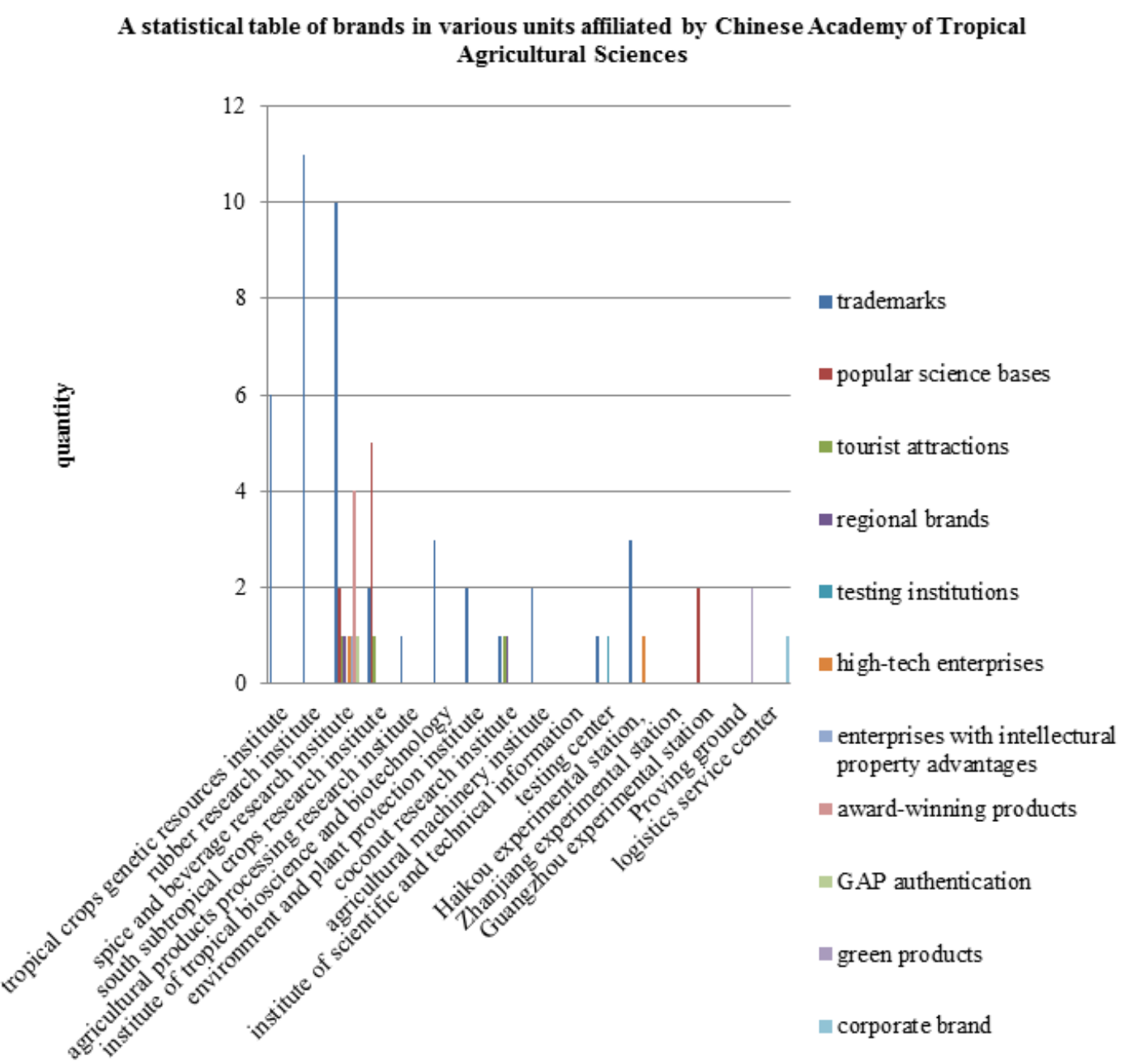

Fig1: A statistical table of brands in various units affiliated by Chinese academy of tropical agricultural sciences

2.2 Development of technology products with tropical characteristics

By way of "joint project approval, joint problem-solving, and joint transformation", the company cooperates with local governments and enterprises and strengthens the industrial connection, which gives full play to the advantages of government organizations, marketing channels of enterprises as well as the scientific and technological support from Chinese Academy of Tropical Agricultural Sciences. Scientific and technological products with tropical characteristics are produced through joint efforts. "Xingke" has been recognized as a famous trademark of Hainan Province. "Xinglong Coffee" and "Wenchang Coconut" have been awarded the title of National Geographic Indications of Agricultural Products and they are also titled top 10 public brands of agricultural products in Hainan Province. Moreover, Xinglong Coffee and Vanilla Tea are also presented with the title of Hainan Province famous-brand products.

\subsection{Construction of a relatively perfect guarantee system}

In order to standardize and improve the cultivation, application, promotion and protection of tropical agricultural

ISSN: 0010-8189

(C) CONVERTER 2021

www.converter-magazine.info 
Volume 2021, No. 5

brands, Chinese Academy of Tropical Agricultural Sciences has formulated the relevant management systems including Brand Construction Guidelines, Work Plan on The Promotion of Tropical Crop Branding, and Guidelines for the Use and Protection of Intellectual Property. The implementation of brand strategies has been listed in the annual assessment in all the units and employees to establish a brand construction mechanism involving the multi-department operation. At the same time, a repository of technology brands is constructed for the statistics, research, sorting and screening of technology brands in the academy. Moreover, some superior products with local characteristics and enterprises are selected according to the plan and procedures so that the key cultivation featured by "one-to-one" and "face to face" gets implemented, such as Xinglong coffee, pepper, jackfruit, Wenchang coconut, etc. The company aims to create brand products and green products with local regional characteristics. The enterprises are sifted to better cultivate those that have a stronger market competitiveness, can continue the research and development and the achievement transformation as well as form the core proprietary intellectual property rights. Priority should be given to those enterprises in terms of policy, capital, technology, publicity in order to build high-tech enterprises, such as Hainan Xingke Xinglong tropical botanical garden development Co., Ltd., and Hainan tropical crops engineering technology Co., LTD., etc.

\subsection{Possession of a relatively perfect monitoring system for agricultural products}

A relatively perfect system of tropical agricultural product standards and quality monitoring is established, and the three-level testing institutions and regulators are set up from towns, counties, cities to provinces. The provincial testing platform of agricultural product quality safety realizes the QR code management of testing reports, standardizes the order of the consumer market for tropical agricultural products, strengthens the responsibility consciousness and entity responsibility of related enterprises, and improves the protection mechanism of consumers' rights and interests. It has not only formulated and improved standards related to tropical agriculture, but also integrated and optimized the national standardized information network platform. In addition, it has also established a quality supervision system that puts prevention first. This has comprehensively enhanced the supervision, efficiency and accuracy, and also ensured that the agricultural products that leave the islands are $100 \%$ up to standard and carry certificates of inspections.

\section{Problems Existing in the Development of Tropical Agricultural Brands}

Hainan has superior natural conditions, high soil fertility, sufficient water resources and light conditions, so it has unique advantages in the development of tropical agriculture [1]. In terms of society, China greatly advocates and supports the proprietary brand construction of tropical agriculture. In addition, governments at all levels of Hainan Province, agricultural businesses and farmers show active interest in developing the brand agriculture. At the same time, Hainan is one of the hot spots recorded by we-media and online celebrity bloggers in China, which lays a good foundation for the development of brand agriculture. However, some practical problems have been found in the construction of brand agriculture, and they are mainly as follows:

\subsection{Improvement of brand construction awareness}

Tropical agricultural production is still carried out by scientific research institutions and local farmers. Though agricultural businesses and farmers show interest in developing the brand agriculture, they fail to realize the importance of the brand construction and mainly focus on products, technology, raw materials and investment because they are limited by technology and specialized knowledge. Thus, the brand construction and the internal quality construction get ignored, and they also lack a strong awareness of brand construction and innovation[2].

\subsection{Brand construction disconnected with market demands}

In the process of agricultural brand construction, the scientific research influence is not effectively transformed into the brand influence. Most of the researchers have insufficient understanding of brand construction, and the products in demand are not prospective. On one hand, the market competition is unprecedentedly fierce. On the other hand,

ISSN: 0010-8189

(C) CONVERTER 2021

www.converter-magazine.info 
Volume 2021, No. 5

products must meet the personalized demands of consumers to seek the differential market positioning. However, the tropical agricultural brand construction dominated by scientific research institutions is not connected with the market. As a result, what the brand construction focuses on is out of line with market demands and industry demands. Moreover, some products are relatively low in technological content, making it unable to support the market share of the brand.

\subsection{Improvement of cooperation and mutual sharing mechanisms}

Brand construction runs through the whole process of enterprise development (products), and it requires support and help from relevant government departments in trademark registration, brand construction and the application and protection of trademarks and brands. At present, the communication and coordination mechanism between units, companies and government departments is far from perfect. Information resources cannot be shared in time without giving full play to their respective advantages. An overall joint working mechanism which integrates consultation in advance, cooperation in the process and sharing afterwards has not been established yet. This is also an important factor to restrict the progress of brand construction.

\subsection{Lack of special funds and professionals}

In the brand cultivation, the lack of special funds for brand construction causes a phenomenon among tropical agricultural products: weak, small scale and scattered. Namely, they are not highly recognized in the market, small in the scale of brand products and also have little profit, which fail to create certain scale effect and market influence[3]. Good brand operation professionals are scarce resources in all walks of life, especially in agriculture[4]. They are required to grasp the expertise of both agriculture and business marketing. In brand operation, on the one hand, we should improve quality, advertise and pay attention to after-sales service; on the other hand, we should build network, build images, do promotion and increase sales volume. They are the two most important aspects of brand operation. They are independent of each other but complementary to each other. It is like a battle: advertising is the vanguard, which is responsible for the popularization among consumers; and then the ground forces (salesmen) carry on in sales channels. It is brand operation that determines the victory and will be finally carried out inside the channels.

\subsection{Improvement of incentive measures}

Incentive mechanism is an open system that constantly innovates along with the changes of the environment, market forms and concrete situations. Since the tropical agricultural brand construction is still in the initial stage, it lacks specific and clear incentive objectives as well as an effective evaluation and supervision mechanism without strict, scientific and systematic evaluation means. In addition, the incentive mechanism is not perfect, and positive and negative incentives are not used properly, which has affected the enthusiasm of relevant personnel to strive for brand work.

\section{Suggestions for Tropical Agricultural Brand Development}

\subsection{Strengthen the foundation of product brand development}

On the one hand, we should adhere to the market orientation, establish the catalog system of tropical agricultural brand products and improve the evaluation system of tropical agricultural products. Meanwhile, activities such as collection, recommendation and release, evaluation and identification should also be organized and carried out in order to select the products that meet the standards for key incubation and promotion. On the other hand, the respective advantages of the government, scientific research institutes, universities and enterprises should be given full play to jointly build a base of tropical agricultural brands as well as build a standardized, advanced and safe transformation platform, improving the quality and influence of brand products [5].

ISSN: 0010-8189

(C) CONVERTER 2021

www.converter-magazine.info 


\subsection{Creation of tropical agricultural brand images}

Combined with the grassroot images of agriculture and We-media, the connotations of tropical agricultural brands are explored and the overall image identification with tropical regional characteristics and agricultural deposits are designed. Moreover, the logos and slogans of brands are packaged and designed to create a more friendly brand image. Also, the relevant intellectual property rights and copyrights are registered to obtain property rights protection. For core products, brand stories are created and we-media is used for the brand image promulgation. As the stories spread among consumers, the spirit of brand is rooted and the brand image is established, which help tropical agricultural products gain profits rapidly and become well-known brands.

\subsection{Cultivation of characteristic high-tech brand products}

New high-tech products such as functional food, healthy forage, green medicine and fertilizer, and intelligent equipment are cultivated with focus. And the scale, industrialization and branding of the products are accelerated in the pilot scale test. The leading or unique product categories or industry standards are created to lead the industry or even guide the formation of national standards. It is aimed to conquer the market and become the industry leader. Combined with regional public brands, the unique differences of tropical agricultural products are linked with the brand, making them the characteristics of the brand. Meanwhile, the differentiation value of products and brands is explored and refined to further popularize and spread.

\subsection{Construction of we-media brand marketing system}

We-media platforms like WeChat, TikTok, Kuaishou, etc. are fully used for publicity instead of using the traditional media such as televisions, newspapers, broadcasting stations, etc. Accurate communication will be carried out by means of live streaming, interaction and products sales by online celebrities, etc., strengthening the interaction with communication targets in the communication process as well as creating a network for publicity, display and communication of tropical agriculture brands. In this way, the brand products leading the market are created with all efforts and resources and the brand reputation also gets strengthened.

\subsection{Marketing channel construction of diversified products}

The brand circulation channel of products is expanded to cover a bigger market share. On the one hand, special resources such as tropical and south Asian tropical botanical gardens and germ plasm resource gardens are affiliated by Chinese Academy of Tropical Agricultural Sciences, and they are used to open stores that exhibit and sell tropical agricultural products as well as to build the basic marketing channels with the terminal consumers. On the other hand, the well-known domestic e-commerce platforms and we-media communication are used to build online shopping malls for brand products. This not only strengthens the online interaction with consumers but also forms a sales network combining online sales and offline sales. At the same time, given that the duty-free stores are expanded at the free trade port in Hainan Province, high-end tropical agricultural products are selected for the market to enhance the value of tropical agricultural brands. In addition, the exclusive shops of brand products integrate display, sales, e-commerce and brand publicity, and they have been set up in key cities all over the country, which enriches the consumers' experience and expands the brand influence.

\subsection{Strengthening in the management and maintenance of brand uses}

The uses of tropical agricultural product brands are standardized. The existing brands are recombined and integrated, and agricultural business units are encouraged to put their existing brands into the marketing system of "tropical agriculture".

In accordance with the requirements specified in the "five unifications" ---unified logo, unified packaging, uniform standard, unified quality tracking system and unified management, the licensed use management and maintenance of "tropical agriculture" brands are strengthened to ensure rights and interests of brands, increase the additional value of

ISSN: 0010-8189

(C) CONVERTER 2021

www.converter-magazine.info 


\section{CONVERTER MAGAZINE}

Volume 2021, No. 5

brands as well as maintain the positive influence and positive images in the society. Through brand equity investment, the academy cooperates with enterprises, participates in merger and reorganization and introduce social capital to better create the brand of "tropical agriculture".

\section{Conclusions}

Although the brand construction of tropical agriculture started late in China and the guarantee mechanisms are still not perfect, we are supported by the leading scientific research force in the field of international tropical agriculture. Hainan government, scientific research institutions and enterprises have also realized the importance of developing proprietary brands of tropical agriculture. The current rapid growth of the we-media brings new opportunities to tropical agriculture.Tropical agriculture should keep up with the times. Supported by Hainan free trade port and the development of "we-media", the construction of proprietary brands should be accelerated to fight for national well-known brands and promote the rapid development of tropical agricultural economy.

\section{Acknowledgement}

The paper was supported by a special project funded by basic scientific research in Chinese Academy of Tropical Agricultural Sciences---research on the marketing system of tropical agricultural science and technology tourism brands.

\section{References}

[1] Y.S. Mo, "Thoughts on Hainan brand agricultural construction," Chinese Agricultural Accounting, vol. 2020, no. 11, pp. 39-41.

[2] X.K. Dong,"Preliminary study on creative agricultural branding construction in Hunan," Guangdong Sericulture, vol. 2020, no.9, pp. 111-113.

[3] X.H. Li,"Research on the current development situation and countermeasures of branding agriculture in Hainan," Chinese Journal of Tropical Agriculture, vol. 2019, no. 11, pp. 127-130.

[4] L.Huang,"Exploration of agricultural brand building and innovations against the background of we-media," Agricultural Economy and Science,vol. 2020, no.8, pp. 190-191.

[5] L.N.Chen, "Analysis of strengths and weaknesses of China's tropic agricultural product marketing and suggestions on experience marketing," Anhui Agricultural Science, vol. 2020, no.48, pp. 235-236.

[6] Q. Zhan,“Agricultural brand building against the background of we-media,” News Sentine,vol. 2019, no. 7, pp. 103-105.

ISSN: 0010-8189 